\title{
Aramaic Traditions from the Qumran Caves and the Palestinian Sources for Part of Luke's Special Material
}

\author{
George J. Brooke
}

The thesis of this paper is that some of the special material in Luke's Gospel, often put together under the acronym $\mathrm{L}^{1}$ resonates with items which are present in Aramaic sources that have become known from the caves at and near Qumran. It is also important to state what this paper will not do with regard to Luke's sources: it is not an attempt, for example, to revisit any form of a Proto-Luke hypothesis that holds that the Gospel is based on a blend of $\mathrm{Q}$ and some other sources into which Luke embedded a number of Markan pericopae. "Questions about Luke's sources must remain unresolved," states Eric Franklin baldly, ${ }^{3}$ and I understand such a statement to indicate the probability that a diverse range of material lies behind the Gospel's distinctive passages, despite any overall awareness of coherence in the final form of the text as perceived by modern scholarly readers. ${ }^{4}$

In other words, the proposal of this study is no more than that Luke seems to have had access, directly or indirectly, to a set or sets of Aramaic traditions, either oral or more likely written or possibly both, which he could use

1 E.g., Kim Paffenroth, The Story of Jesus according to L, JSNTSup 147 (Sheffield: Sheffield Academic Press, 1997), which is a strong or maximalist reading of what can be claimed for $\mathrm{L}$ for Luke 3-19; in his review Christopher M. Tuckett, NovT 41 (1999): 191-92, states: "Paffenroth has made a strong case for the claim that an L source may have existed. Even if the force of the argument varies at different points (as is inevitable), he is fully justified in raising the questions about the origins of Luke's special material and forcing us all to reconsider older stereotypes."

2 To be kept in mind also is the possibility that Q reflects Aramaic traditions of its own; see, e.g., Simon J. Joseph, The Nonviolent Messiah: Jesus, Q, and the Enochic Tradition (Minneapolis, MN: Fortress Press, 2014).

3 Eric Franklin, "Luke," in The Oxford Bible Commentary, ed. John Barton and John Muddiman (Oxford: Oxford University Press, 2001), 924.

4 In another study, I have suggested that some parts of $\mathrm{L}$, those with shared traditions with the Fourth Gospel, also have early Judean settings: George J. Brooke, "Luke, John and the Dead Sea Scrolls," in John, Qumran, and the Dead Sea Scrolls: Sixty Years of Discovery and Debate, ed. Mary L. Coloe and Tom Thatcher, SBLEJL 32 (Atlanta, GA: SBL, 2011), 69-91. 
as a resource as he sought to tell and retell his version of the Gospel. If Luke's acquaintance with such material was indirect, then those early Jewish literary traditions could have already been translated in written form from Aramaic to Greek, as is now clearly visible in Judea itself for some of the Enoch materials which are known in both Aramaic from Cave 4 and Greek from Cave $7 .^{5}$ Whereas Joseph Fitzmyer in his 1970 presidential address to the Catholic Biblical Association could still feel the need to make a case for Aramaic as the most common spoken language in Palestine at the time of Jesus, his own conclusion that indeed it was has become generally accepted. In addition, there is evidence that Aramaic was used for various technical documentary purposes, even though there is sound testimony for the use of Hebrew and Greek as well. ${ }^{6}$ Thus it remains the case that although some traditions might have been most readily known in Aramaic, those same traditions could already also be known in Judea and beyond in Greek. ${ }^{7}$

Two brief introductory remarks will set the scene for this essay which is an attempt to revisit the topic of the background of at least some of the special material in Luke.

First, the Aramaic compositions from the Qumran caves are overwhelmingly or completely non-sectarian religious literature. Although one composition, $4 \mathrm{QVisions}$ of Amram ${ }^{\mathrm{f}}$ ar $\left(4 \mathrm{Q}_{548} \mathrm{ii}-2\right.$ 16), does indeed use the label "sons of light," which was later to become a technical designation of the movement, or part of it, which preserved the composition, there is an ongoing debate as to whether that is sufficient evidence that this Aramaic work merits the label "sectarian," and it also seems to be a different composition from the Visions of Amram preserved in 4 Q $543-547 .{ }^{8}$ Rather the case seems to be that the Aramaic corpus from the Qumran caves should be understood as predominantly, even

5 On the Aramaic to Greek phenomenon in Judea in the first centuries BCE and CE see the notable articles by James Barr, "Aramaic-Greek Notes on the Book of Enoch I," JSS 23 (1978): 184-98; idem, "Aramaic-Greek Notes on the Book of Enoch II," JSS 24 (1979): 179-92. See also Barr's review of Józef T. Milik, The Books of Enoch, JTS 29 (1978): 517-30. On issues in retroversion from Greek to Aramaic, especially with regard to the sayings of Jesus, see the cautious remarks by Edward M. Cook, "Qumran Aramaic, Corpus Linguistics, and Aramaic Retroversion," DSD 21 (2014): 373-83.

6 Joseph A. Fitzmyer, "The Languages of Palestine," свQ 32 (1970): 501-31; repr. in idem, A Wandering Aramean: Collected Aramaic Essays, sblms 25 (Missoula: Scholars Press, 1979), 29-56.

7 It is interesting to note that only Greek and Hebrew are considered as the language of all parts of Luke's infancy narrative by Chang-Wook Jung, The Original Language of the Lukan Infancy Narrative, JSNTSup 267 (London: T\&T Clark International, 2004), esp. 32, n. 87.

8 Robert R. Duke, The Social Location of the Visions of Amram (4Q543-547), StBibLit 135 (New York: Peter Lang, 2010), 35-37. 
exclusively, non- or pre-sectarian. ${ }^{9}$ It was certainly preserved by some members of the "sectarian" movement in their caves, it was probably read by them with interest, and not just at Qumran, and it is demonstrable that at least some of the ideas of some of the Aramaic works influenced the movement's perspective on various matters. ${ }^{10}$ Thus, much of the material in the Aramaic compositions could be used sympathetically by the movement who preserved the compositions in their caves, but it was not narrowly "sectarian" in itself."

Second, ideologically the Aramaic corpus carries some features, though not uniformly, that distinguish it from contemporary Jewish literature in Hebrew or Greek. The distinction is a matter of nuance and emphasis in many cases, rather than having to do with exclusive differences: some of those ideological traits concern a stress on the traditions of the ancestors, an interest in particular priestly lore, especially as that is carried by books and apparently marked by esoteric knowledge rather than competence in sacrificial cultic matters, and there are also somewhat differing perspectives on evil, on angels and on the covenant. ${ }^{12}$ It is possible that some of those ideological differences reflect the different cultural context of Aramaic-speaking Jews in the eastern diaspora, but such observations often involve the weighing of multiple factors and rest on several uncertainties, such as where some compositions were actually composed. For $4 \mathrm{Q} 246$, for example, a case has been made that its contents

The most explicit attempt to map the character of the Aramaic compositions found in the Qumran caves has been made by Devorah Dimant; see especially her essay, "Themes and Genres in the Aramaic Texts from Qumran," in Aramaica Qumranica: Proceedings of the Conference on the Aramaic Texts from Qumran in Aix-en-Provence 30 June-2 July 2008, ed. Katell Berthelot and Daniel Stökl Ben Ezra, STDJ 94 (Leiden: Brill, 2010), 15-43; repr. in Devorah Dimant, History, Ideology and Bible Interpretation in the Dead Sea Scrolls: Collected Studies, FAT 90 (Tübingen: Mohr Siebeck, 2014), 195-218. See also the valuable comments of Eibert J. C. Tigchelaar, "Aramaic Texts from Qumran and the Authoritativeness of Hebrew Scriptures: Preliminary Observations," in Authoritative Scriptures in Ancient Judaism, ed. Mladen Popović, JSJSup 141 (Leiden: Brill, 2010), 155-71, who discusses the possibility of pre-Maccabean Aramaic compositions carrying authority.

$10 \quad$ E.g., the myth of the Watchers is reflected in $\mathrm{D}$ (CD 2:14-20).

11 This is also the suitable opinion of John J. Collins, "The Aramaic Texts from Qumran: Conclusions and Perspectives," in Berthelot and Stökl Ben Ezra, Aramaica Qumranica, 554-55.

12 Another attempt at outlining some of the distinctive characteristics of the Aramaic material is that of Andrew B. Perrin, The Dynamics of Dream-Vision Revelation in the Aramaic Dead Sea Scrolls, JAJSup 19 (Göttingen: Vandenhoeck \& Ruprecht, 2015). See also Ariel Feldman, "Patriarchs and Aramaic Traditions," in T\&T Clark Companion to the Dead Sea Scrolls, ed. George J. Brooke and Charlotte Hempel (London: T\&T Clark, 2019), 469-80: "the notion of the transmission of knowledge within the patriarchal line is particularly endorsed by the non-sectarian Aramaic texts from Qumran" (p. 478). 
echo features of Akkadian texts, but others would rather associate it with preDanielic tradition of a different kind. ${ }^{13}$

Joseph A. Fitzmyer attended a lecture presented by Józef T. Milik at Harvard University in 1972 which included reference to 4 Q246. Fitzmyer published an article on the text soon thereafter and the text has been the focus of much discussion ever since because it mentions a figure who is named as "son of God" and "son of the Most High."14 In fact, such has been the interest in the remains of this composition that it has even been designated as "the Son of God text," though now it is officially known as "246. 4QApocryphe de Daniel ar."15

There are two approaches to the referents of the most well-known section of text, and some permutations within those two approaches. ${ }^{16}$ The first approach reflects the initial impression of Milik that the referent is negative. For Milik the person behind the claims to divine sonship is a wicked selfpromoting person of power, possibly a member of the Seleucid royal line making assertions about his own status or that of an heir to bolster his position. Perhaps out of respect for Milik's original proposals, Émile Puech in his principal edition of the work proposes that the text could refer to Alexander

13 Edward M. Cook, “4Q246," ввR 5 (1995): 43-66, has suggested that the background of 4Q246 lies in Akkadian prophecies. Though there may be some few shared features and idioms, overall the criticism of John J. Collins, "The Background of the 'Son of God' Text," $B B R 7$ (1997): 51-62, seems fully justified: Collins argues that Daniel is the immediate correlative for $4 \mathrm{Q} 246$.

14 Joseph A. Fitzmyer, "The Contribution of Qumran Aramaic to the Study of the New Testament," NTS 20 (1973-74): 382-407 (391-94); repr. in idem, A Wandering Aramean, 85-113 (90-94; with addendum 102-107). Fitzmyer has published further on the text in "The Aramaic 'Son of God' Text from Qumran Cave 4," in Methods of Investigation of the Dead Sea Scrolls and the Khirbet Qumran Site: Present Realities and Future Prospects, ed. Michael O. Wise, Norman Golb, John J. Collins and Dennis G. Pardee, Annals of the New York Academy of Sciences 722 (New York: The New York Academy of Sciences, 1994), $163-78$.

15 The principal edition is by Émile Puech, "246. 4QApocryphe de Daniel ar," Qumran Cave 4.XVII: Parabiblical Texts, Part 3, ed. James VanderKam, DJD 22 (Oxford: Clarendon Press, 1996), 165-84.

16 For more detail on the various interpretations of the son of God in 4 Q246 see Reinhard Kratz, "Son of God and Son of Man: 4Q246 in the Light of the Book of Daniel," in Son of God: Divine Sonship in Jewish and Christian Antiquity, ed. Garrick Allen et al. (University Park, PA: Eisenbrauns, 2019), 9-27; Kratz himself prefers understanding the son of God figure negatively. See also Melissa Sayyad Bach's article in the present volume. 
Balas (Alexander Theopator ${ }^{17}$ Euergetes), son of Antiochus IV Epiphanes, or possibly to Antiochus Epiphanes himself. ${ }^{18}$ Puech sees the text as comparable to Josephus's comment on Caligula: "The insolence with which the emperor Gaius defied fortune surpassed all bounds: he wished to be considered a god and to be hailed ( $\kappa \alpha \lambda \varepsilon i \sigma \theta \alpha$ ) as such" (War 2:184). In one estimate this would be akin for a Jewish author to the hubris of an antichrist. ${ }^{19}$

In subsequent and especially recent scholarship the negative understanding has been adopted by those who pay attention to the structure of the passage as a whole. That the most positive aspect is reserved for the eschatological sovereignty of the people of God was first mapped out extensively by Annette Steudel. ${ }^{20}$ A negative understanding is also adopted by Michael Segal and Reinhard Kratz. For Segal, the text builds up a negative sequence: (a) 1:1-8, a time of trial and tribulation under the king(s) of Assyria and Egypt; (b) 1:9-2:2, the so-called "son of God"; (c) 2:2-3 the nations fighting against each other; and (d) 2:4-9, the positive scene of the eschatological sovereignty of the people of God. For Segal, two matters are significant, namely, that it is possible to read the verbal forms in 1:9-2:2 as implying "so-called," and that the titles need to be juxtaposed with the language of Ps $82 .{ }^{21}$ Segal's overall proposal, then, is that in the light of Dan 7 in combination with Ps $824 \mathrm{Q}_{246}$ makes the socalled son of God likely to be the representative in the divine assembly of the fourth (Greek) kingdom that is about to be destroyed. ${ }^{22}$ For Kratz attention to the likely structure of the surviving part of the composition gives a pattern in which the "son of God" is also to be viewed negatively. ${ }^{23}$

The second approach understands the text to be making a positive set of claims for a Jewish king in an apocalyptic context who is represented in the

17 "Theopator" makes Alexander son of a divine father, "son of God."

18 It is such an identification that is adopted by Reinhard Kratz, "Son of God and Son of Man.".

19 David Flusser, "The Hubris of the Antichrist in a Fragment from Qumran," Imm 10 (1980): 31-37.

20 Annette Steudel, "The Eternal Reign of God-Collective Expectations in Qumran Texts (4Q246 and 1QM)," RevQ 17 (1996): 507-25.

21 Partly because of Ps 82, I have juxtaposed Luke 1:32-35 with John 10:22-39 (where the Psalm is explicitly cited) as an instance of where Luke and John might share some traditional material. In John 10 the association with the Feast of Hanukkah is explicit so that Jesus as God's son is implicitly and antithetically juxtaposed with that of Antiochus Epiphanes: Brooke, "Luke, John and the Dead Sea Scrolls," 83-85.

22 Michael Segal, "Who is the 'Son of God' in 4Q246? An Overlooked Example of Early Biblical Interpretation," DSD 21 (2014): 289-312.

23 Reinhard G. Kratz, "Son of God and Son of Man," 24-27. 
speech by the speaker as he stands before a foreign king. ${ }^{24}$ That was initially articulated by Fitzmyer: "The context of the fragmentary text deals with a political strife, in which the 'son of God' figure is hailed as the harbinger of peace and everlasting dominion, as a bearer of those things associated with the restoration of Davidic kingship." ${ }^{25}$ Fitzmyer resists identifying the figure as messianic; others, especially John Collins, have not been so cautious, and possibly justifiably so. ${ }^{26}$

My own preference has been to see that at least one reader of this tradition, if not this actual composition, namely the author of Luke's Gospel, took the nomenclature and several other features of the tradition in a positive and messianic manner, even if they had been inappropriately adopted by a pretender. The correspondences between $4 \mathrm{Q}_{246}$ and the Lukan infancy narrative are striking. ${ }^{27}$ In Luke 1:32-35 the same pair of titles occurs together with the phrase "he will be great" (the beginning of verse 32 reads oi $\tau 0 \varsigma$ है $\tilde{\sigma} \tau \alpha l \mu \varepsilon$ ' $\gamma \alpha \varsigma$

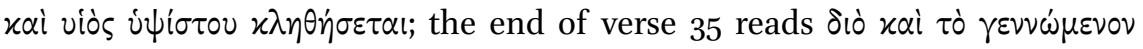
ayıov $x \lambda \eta \theta \dot{\eta} \sigma \varepsilon \tau \alpha$ viós $\theta \varepsilon \circ \hat{v})$. Collins comments that these correspondences are "astonishing" and that "it is difficult to avoid the conclusion that Luke is dependent in some way, whether directly or indirectly, on this long-lost text from Qumran." ${ }^{28}$ Here, then, in Luke's infancy narrative we have an example of the messianic reading of the text, and a reading that took the figure as an individual. In such a case, depending upon how close one considers Luke to be to the tradition, if it is thought of as originally describing a negative figure, he either misunderstood or deliberately subverted the earlier tradition to make the use of the titles entirely positive. Luke does not seem averse to subversion, since by setting the beginnings of the Gospel in the times of a decree from the Emperor Augustus, he would most likely have known that the title with which he describes Jesus is already claimed by the Emperor himself. If the Son of God figure in $4 \mathrm{Q}_{246}$ is to be read positively, as an eschatological or even messianic figure, then the same result is more easily reached. ${ }^{29}$

24 A position favoured by John J. Collins in Adela Yarbro Collins and John J. Collins, King and Messiah as Son of God (Grand Rapids, MI: Eerdmans, 2008), 70-73.

25 Fitzmyer, "The Contribution," 106.

26 Adela Yarbro Collins and John J. Collins, King and Messiah as Son of God, 65-74, 143-44.

27 It is a moot point whether the Lukan infancy narratives should be seen as part of $\mathrm{L}$ or as a separate source. Kim Paffenroth, The Story of Jesus according to L, 27-28, sides with those who distinguish Luke 1-2 from the rest of L. Nevertheless, the Palestinian Jewish character of much of Luke 1-2 cannot be denied.

28 Collins, "The Messiah as the Son of God," 155.

29 Hengel, Son of God (London: SсM Press, 1976), 45, has stated: "Nor is it possible to rule out a collective interpretation in terms of the Jewish people, like the Son of Man in Dan. 7.13." See, for the collective interpretation, Sayyad Bach's article in the present volume. 
Having noted that Luke 1:32-35 resonates with this Aramaic tradition, whether the original intention of the text was negative or positive, it is worth noting that Jesus is called both Son of God and Son of the Most High. The motif of the Son of God occurs again in the opening sections of Luke's Gospel at the baptism of Jesus where its use depends upon Mark, in the genealogy where the sonship eventually involves the descent of Adam from God himself, in the temptation narrative which seems to depend upon Q, and in the summary of his healing ministry in Luke 4:40-41. It is not too far-fetched to suppose that Luke develops his theme of "Son of God" by considering that both Mark and Q need to be supplemented by adding material which can support a reading of Jesus's sonship as that emerges from the application of and reflection upon early Palestinian traditions in Aramaic or in translation from Aramaic.

\section{$3 \quad$ Luke's Genealogy and the Books of Enoch}

This section of my presentation is based in large part on the insights of Richard Bauckham in a richly researched book which seems to be seldom referred to, but which has several significant observations about the traditions involving the family of Jesus, Jude and the Relatives of Jesus in the Early Church. ${ }^{30}$ In Chapter 7 of his book Bauckham writes about the Lukan genealogy of Jesus. His overall concern is to argue that it "is a more important historical document than has generally been appreciated." ${ }^{31}$ The history that Bauckham seeks to disclose concerns the circle of the first generation of the desposynoi; he explores how the genealogy might incorporate "the family's own tradition of its ancestry."32 A major contribution of the analysis is an exposition of the Enochic character of various aspects of the genealogy.

There are several features of the Enochic character which, when taken together, suggest strongly that the form of the genealogy that Luke presents is not his own, but is based on Aramaic traditions available to him either directly or indirectly. First, there is the scheme of the genealogy itself. It consists of seventy-seven human generations from Adam to Jesus. Bauckham construes the final words identifying Adam as son of God as Luke's redaction. That might very well be the case, but it is in my opinion a redaction which is in part at least motivated by the inclusion of the titular designations, including Son

$30 \quad$ Richard J. Bauckham, Jude and the Relatives of Jesus in the Early Church (Edinburgh: T\&T Clark, 1990).

31 Bauckham, Jude and the Relatives of Jesus, 315.

32 Bauckham, Jude and the Relatives of Jesus, 315. 
of God, from another Aramaic tradition (4Q246; see above) in Luke 1:32-35, together with reflection on the need to enhance material taken over from Mark and Q. ${ }^{33}$ Most scholars have readily identified the scheme of the genealogy as having eleven sets of seven generations and have proposed that Jesus lies at the turning point to inaugurate the twelfth set, in a scheme designed to reflect on the symbolic significance of twelve. For Bauckham the scheme is not one of incompleteness, but of the completeness of eleven times seven, namely, seventy-seven (cf. Gen 4:24; Matt 18:22). In seventh place in the genealogy stands Enoch himself; such a position is commonly attested in contemporary compositions (1 En. 6o:8; 93:3; Jub. 7:39; Jude 14). Bauckham wonders just what the significance might be of the correlation between Enoch as seventh and Jesus as seventy-seventh; if Enoch is special in some way, then Jesus must be special in some ultimate manner. Indeed, such seems to be anticipated inasmuch as the significant name at the forty-ninth, seven times seven, position is also Jesus (Luke 3:29).

For the numerical scheme, it seems that the key base text is to be found in 1 En. $10: 12\left(4 \mathrm{QEn}^{\mathrm{b}} 1\right.$ iv 10). There the archangel Michael is told to bind the Watchers "for seventy generations under the hills of the earth until the [great] day of their judgment." ${ }^{34}$ It is likely that the binding is envisaged as taking place after Enoch's ascent, during the lifetime of his son Methuselah. Thus, the last judgement will occur in the seventieth generation thereafter; in the light of such a scheme Jesus is the last generation before the judgement. The schematisation in groups of seven generations is also found in the so-called Apocalypse of Weeks (1 En. 93:3-10; 91:11-17) where the periods from Adam until the judgment are ten; there is a discrepancy with what is implied in 1 En. 10:12 since the Apocalypse of Weeks has counted the first set of seven from Adam to Enoch as part of the overall ten-week scheme. Quite how the Apocalypse of Weeks might have populated each generation with a significant figure requires some use of traditions beyond those also found in scriptural texts; but the Apocalypse is less concerned with named generations and more concerned with key events, such as Sinai, the building and destruction of the Temple, and the identification of its own group and its acquisition of Enochic revelation in the key forty-ninth position, leaving three weeks for the future.

33 Michael Kochenash, "Adam, son of God' (Luke 3:38): Another Jesus-Augustus Parallel in Luke's Gospel," NTS 64 (2018): 307-25, has argued that the implied designation Son of God in Luke 3:38 is a Lukan way of setting Jesus as a counterpart to Augustus who was adopted as divine, implying that Joseph did indeed adopt Jesus.

34 Trans. Michael A. Knibb, The Ethiopic Book of Enoch, 2 vols. (Oxford: Clarendon Press, 1978), 2:89; with "great" added to the Ethiopic from the Aramaic as in the discussion of the passage by Bauckham, Jude and the Relatives of Jesus, 320 . 
Overall, through its dependence on the Enochic scheme of eleven sets of seven generations, the Lukan genealogy sets judgment imminently in the generation of Jesus's contemporaries. For Bauckham it is no accident that the Letter of Jude 6 echoes the phrase "the great day of their judgment" of 1 En. 10:12: "The angels, too, who did not keep their own position of authority, but abandoned their proper home [cf. 1 En. 12:4; 15:3, 7], he has kept in eternal chains in the nether darkness [cf. 1 En. 10:4-6] until the judgment of the great day." ${ }^{\prime 35}$ And he further remarks that the reference to Enoch as seventh from Adam in Jude 14 strongly suggests some contact with the key elements that are foundational to the construction of Jesus' genealogy as it features in Luke. ${ }^{36}$

Luke has given a Davidic twist to some aspects of the genealogy. David is named in the final position of the fifth week of generations. ${ }^{37}$ Final position in each week seems to be significant. In Luke's list the name Joseph occurs at the end of the sixth and tenth set of seven generations in anticipation of the final Joseph whose son is Jesus. But in a more Enochic style, the third position also seems to carry weight. Third from Adam is Enosh, the founder of prayer, the third in the second set of seven is Noah, the first to offer sacrifice after the flood, third in the seventh and eleventh sets of seven is Levi. Indeed, if the priestly genealogy from Ezra 7:1-5 is encoded alongside that of Luke 3, placing Levi alongside Judah (also in third place, in the fourth set of seven), then Zadok features as third in the sixth set of seven. The discreet prominence of Enosh and Levi in particular echo other Aramaic traditions in which Levi is the heir to priestly lore and the transmitter to Qahat and Amram of such priestly knowledge as might be set down in books. The Aramaic compositions associated with that priestly tradition might well lie behind and even inform Luke's considerable interest in the Temple and inclusive worship. Indeed, much in both the infancy narrative and the final scene of the Gospel are set in the Temple and a concern for inclusive worship seems to lie behind Luke's

35 The presence of "great" in both Aramaic Enoch and Jude indicates Jude's close connection with the Aramaic tradition: see further Richard J. Bauckham, Jude, 2 Peter, wBC 20 (Waco, TX: Word Publishing, 1983), 52-53.

36 Because of the coincidence in Jude of the echo of 1 En. 10:12 and the explicit note there of Enoch as seventh from Adam, Bauckham, Jude and the Relatives of Jesus, 364, dares to conclude: "If the genealogy is not the work of Jude himself, it must certainly have come from his circle."

37 Bauckham, Jude and the Relatives of Jesus, 328-47, has an extensive treatment of Zerubbabel, first in the ninth set of seven generations. He argues that his title as rôš was misread as a proper name by the Aramaic-speaking compiler of the genealogy to give the name Rhesa. The title could well be an assertion that Zerubbabel was indeed understood as the national "leader," the legitimate heir to the Davidic line despite his descent. 
interests in shepherds, in Samaritans, in women, and possibly in those whose ailments and disabilities might also exclude them from the cult.

\section{$4 \quad$ The Laying on of Hands}

The two examples that have been discussed so far belong to Luke's introductory chapters where there is indeed a greater amount of distinctively Lukan material than in most other parts of the Gospel. However, in Luke 13:10-17 there is a distinctive healing narrative in which Jesus lays his hands on the woman whom he restores; the healing narrative is framed within a Sabbath controversy story.

Now he was teaching in one of the synagogues on the Sabbath. And just then there appeared a woman with a spirit that had crippled her from eighteen years. She was bent over and quite unable to stand up straight. When Jesus saw her, he called her over and said, "Woman, you are set free from your ailment." When he laid his hands on her, immediately she stood up straight and began praising God. But the leader of the synagogue, indignant because Jesus had cured on the Sabbath, kept saying to the crowd, "There are six days on which work ought to be done; come on those days and be cured, and not on the Sabbath day." But the Lord answered and said, "You hypocrites! Does not each of you on the Sabbath untie his ox or his donkey from the manger, and lead it away to give it water? And ought not this woman, a daughter of Abraham whom Satan bound for eighteen long years, be set free from this bondage on the Sabbath day?" When he said this, all his opponents were put to shame; and the entire crowd was rejoicing at all the wonderful things that he was doing. (NRSV)

This narrative was noticed early on by David Flusser and others because the means of healing used by Jesus seems to echo that of Abram in 1QapGen 20:26-30. The Egyptian king calls Abram and says to him:

"What have you done to me?! Why were you saying to me 'she is my sister' when she was your wife, so that I took her as a wife for myself?! Here is your wife. Take her, go and get yourself out of every district of Egypt! But now pray over me and my household, that this evil spirit may be driven away from us." So I prayed over [hi]m that I might heal him, and I laid my hands upon his $[\mathrm{h}]$ ead. Thus, the affliction was removed from him, and 
the evil [spirit] driven away [from him]. The king recovered, rose up, and gave to me on $\mathrm{t}\left[\right.$ hat da]y many gift $[\mathrm{s}] .{ }^{38}$

The most recent comprehensive consideration of Luke 13 in the light of the early Aramaic traditions from the Qumran caves has been presented by Daniel Machiela. ${ }^{39}$ In my opinion Machiela notes two significant matters. First, in his opinion in some texts it is clear that physical healing and deliverance from an evil spirit belong together as two sides of the same coin. ${ }^{40}$ In Luke 13 the healing of the woman is indeed both a physical matter and also the deliverance from an evil spirit that has possessed her; she is said to have a "spirit of infirmity" (cf. Luke 6:18; 8:2, 36). Machiela's insistence on keeping the two aspects together calls into question the preference of some modern commentators to see the combination of features in Luke as indicative of Luke imposing his own editorial concerns on the narrative ${ }^{41}$ In the light of some other Gospel evidence Machiela sees the combination as reflective of the times: "Evidently, the borders between demon possession, physical illness, and the need for healing were blurry ones in the first century."42 Such a view is underpinned by consideration of similar combined motifs of knowledge about medicine and evil spirits in Jub. 10:11-13, probably based on traditions in 1 En. 1-36.

Second, and of equal importance, is the way that Machiela compares the healing in Luke 13 with Luke's presentation in the triple tradition of the general statements about Jesus's healing activity based on Mark 1:32-34 (// Matt 8:16-17). The parallel passage in Luke 4:40-41 reads "As the sun was

38 Trans. Daniel A. Machiela, The Dead Sea Genesis Apocryphon: A New Text and Transltion with Introduction and Special Treatment of Columns 13-17, STDJ 79 (Leiden: Brill, 2009): 76-77. Loren Stuckenbruck wonders quite what the process of rebuke or exorcism is in the passage: is it a matter of expulsion from the house or household, or from Pharaoh as an individual? See Loren Stuckenbruck, 'Qumran Aramaic' Today: Reflections on the Contributions in the Issue of Dead Sea Discoveries," DSD 21 (2014): 285 .

39 Daniel A. Machiela, "Luke 13:10-13: 'Woman, You Have Been Set Free From Your Ailment'Illness, Demon Possession, and Laying on of Hands in Light of Second Temple Period Jewish Literature," in The Gospels in First-Century Judaea: Proceedings of the Inaugural Conference of Nyack College's Graduate Program in Ancient Judaism and Christian Origins, August 29th, 2013, ed. R. Steven Notley and Jeffrey P. García, Jewish and Christian Perspectives 29 (Leiden: Brill, 2015), 122-37.

40 Machiela, "Luke 13:10-13," 126, makes an insightful comment on Mark 1:32-34, noting that the NRSV translation imposes on the text an assumption that separates illness from demon possession.

41 Machiela, "Luke 13:10-13," 126, notes, e.g., how Graham H. Twelftree, Jesus the Exorcist, WUNT II.54 (Tübingen: Mohr Siebeck, 1993), 55-56, in his treatment of the passage argues that Luke has edited the tradition for his own interests.

Machiela, "Luke 13:10-13," 124. 
setting, all those who had any who were sick with various kinds of diseases brought them to him; and he laid his hands on each of them and cured them. Demons also came out of many, shouting, 'You are the Son of God!' But he rebuked them and would not allow them to speak, because they knew that he was the Messiah." In this Lukan version of the summary narrative, the mention of the laying on of hands and the demons' exclamatory confession of Jesus as Son of God are distinctive of Luke. I will return to those matters in a closing section below.

Machiela then proceeds to work through some of the details of the Aramaic counterparts, especially to Luke 13:10-13, including alongside the Genesis Apocryphon the book of Tobit, because it too was initially composed in Aramaic. For the Genesis Apocryphon he has noted several features. First, the plagues that strike Pharaoh and his household are associated with evil spirits, a "pestilential spirit" (20:16), an "evil spirit" (20:16-17), a "spirit of pollutions" (20:26). Second, Harkenosh assumes Abram has power over spirits which the king's magicians and healers do not have (20:21-23), a power that reflects the same kind of specialist knowledge associated with divine favour as is found in Abram's skills in writing, wisdom and truth which make him sought after (19:23-29). Third, Machiela has noted that such power and knowledge are explicitly associated with the figure of Enoch (19:25, 29), not unlike what was said of Noah's insights in Jub. 10. Fourth, two items in the language of the Apocryphon (smk and 'tg'r) are widely held also to lie behind the choice of epitithēmi and epitimāo (rebuke) as occur in Luke 4:40-41. ${ }^{43}$

The second of those terms, $g^{\prime} r$, has been the subject of a detailed study by Jan Joosten who has argued that between the use of the root in Hebrew in Zech 3:2 where it does not denote exorcism and its later use on amulets where it does, there is delocution in Aramaic. In Zech 3:2 the Hebrew reads "Yhwh said to the adversary (haśätān), 'May Yhwh rebuke you (yig'ar), adversary! May Yhwh who has chosen Jerusalem rebuke you!" Joosten is clear that no exorcism is involved and he even denies the presence of any kind of formulaic use; but the verse was certainly used for exactly such purposes as in early amulets and in $b$. Ber. $5^{1 a}$ when one is threatened by the angel of death. Joosten includes Jude 9 in his list of examples of exorcism, but this is disputed by Loren Stuckenbruck who argues, rightly in my opinion, that Jude 9 only concerns a confrontation between Michael and the adversary in a dispute over the body of Moses, rather than the expulsion of something from the body ${ }^{44}$ Delocution is the derivation

43 On $g^{\prime} r$ see Jan Joosten, "The Verb $g^{\prime} r$ 'to Exorcise' in Qumran Aramaic and Beyond," DSD 21 (2014): 347-55.

44 Stuckenbruck, “Qumran Aramaic' Today," 284-85. 
of meaning from formulaic locution; so $g^{\text {' }}$ means in effect "to say 'May the Lord rebuke you', to exorcize by reciting Zech 3:2."45 For Joosten the shift between Zech 3:2 as written and the use of $g^{\prime} r$ in the Genesis Apocryphon in the sense of "exorcize" is an indication that the term had a specificity in religious practice in specifically Jewish circles. The Aramaic of the Genesis Apocryphon has to some extent been judaized.

With particular attention to Luke 13, there are three matters. First, the spirit of infirmity (pneuma astheneias) can be juxtaposed with the "spirit of plague" $(r w h$ mkds) of the Genesis Apocryphon. Second, Abram's words of healing in the Apocryphon are described as prayer, and that is another strong indicator that it is not necessary to suppose that words of prayer in such narratives in the Gospels are later editorial additions. Third, the order of spoken command, laying on of hands, and healing is common to both the Apocryphon and Luke. All three factors assist in encouraging the view that Luke's narrative concerning the healing of the bent woman reflects not just early tradition but traditions as conveyed in Aramaic. Perhaps of particular pertinence is the way such Aramaic traditions are based on or associated with the role of Raphael who in 1 En. 10:4-9 is charged with healing the earth from the effects of the watchers. That section of 1 Enoch seems to be significant for Luke's genealogy, as mentioned in the previous section of this study.

Overall comparison between 1 Enoch, Tobit, Jubilees, the Genesis Apocryphon and Luke's Jesus prompts Machiela to wonder whether at least some of the differences in the various narratives reflect some kind of understanding that the figures concerned had various levels of authority. Tobiah requires the accompanying assistance of Raphael, but Noah, Abram, and even Jesus seem to be able to function without such assistance, perhaps because they are the heirs of the knowledge of medicine and spirits possessed and passed on by Enoch. Jesus's genealogy indirectly makes the same point, amongst several others.

In the light of what I have juxtaposed in this paper, I am inclined to wonder whether Luke's concern with an Aramaic tradition for the basis of confession of Jesus as Son of God is not itself reinforced twice from reflecting on that very Aramaic tradition, namely in the Enochic-like genealogy in which Jesus's lineage is understood as based on that of the first Son of God, and in Luke 4 in which it is the demons who immediately recognize Jesus in the same way as "Son of God." In between Luke has rehearsed his version of the tradition he has in common with Matthew in which Jesus is tempted by the devil, twice with the words, "If you are the Son of God" (Luke 4:3, 9).

45 Joosten, "The Verb g'r 'to Exorcise' in Qumran Aramaic and Beyond," 354. 
If it is not possible to conclude anything precise about the literary cohesiveness of the Aramaic sources which Luke seems to reflect in some of his distinctive material, it is also difficult to say anything much about their likely location. Nevertheless, in a 1981 essay George W. E. Nickelsburg wondered about placing various traditions about Enoch, Levi and Peter in Upper Galilee. ${ }^{46}$ Nickelsburg highlights how within the three parallel sections of 1 En. 12-16 which are themselves a kind of commentary, as he sees it, on the narrative of the angelic rebellion of 1 En. 6-11, there is geographical specificity: Enoch's journey to the heavenly throne room originates as follows, "I went and sat by the waters of Dan in the land of Dan, which is southwest of Hermon" (13:7); and when he wakes up he goes to the Watchers who are "sitting and weeping at Abel-Main, which is between Lebanon and Senir" (13:9). Nickelsburg also recalls that in 1 En. 6 the descent of the rebel angels took place on Mount Hermon. For Nickelsburg it is clear that much in the Enoch corpus has a referential and reverential eye on eschatological Jerusalem, but he considers that Dan and its environs receive such an explicit mention in $1 \mathrm{En} .13$ because there were traditions of northern Galileean provenance "which, in turn, reflect visionary activity in the area of Dan and Hermon,"47 "the old sacred territory around Dan was recognized as sacred by our author and that it served as a locus that was catalytic of revelation," 48 and could be a source for a polemic against contemporary priestly practices in Jerusalem, a similar polemical stance as might be taken up later by the movement part of which ended up preserving Enochic materials at Qumran. For Nickelsburg, similar geographical interests are explicit in the Testament of Levi: Levi shepherds his flock at Abel-Maîn (T. Levi 2:3), and in a vision he is taken to the top of Mount Hermon (T. Levi 2:5). The Eshels concur that Hermon is indeed a significantly holy site in the Book of Watchers, though they are hesitant on that basis to agree that northern Galilee was the

46 George W. E. Nickelsburg, "Enoch, Levi, and Peter: Recipients of Revelation in Upper Galilee," JBL 100 (1981): 575-6oo; repr. in Jacob Neusner and Alan J. Avery-Peck, eds., George W. E. Nickelsburg in Perspective: An Ongoing Dialogue of Learning, 2 vols., JSJSup 8o (Leiden: Brill, 2003), 2:427-57, with some comments by Hanan Eshel and Esther Eshel (pp. 458-68) who differentiate the geographical references in the sources, distinguishing 1 Enoch, as Galilean, from the others as from other areas. More detailed comments confirming some aspects of the ideas of both Nickelsburg and the Eshels have been made by David W. Suter, "Why Galilee? Galilean Regionalism in the Interpretation of 1 Enoch 6-16," Hen 25 (2003): 167-212, though Suter does not comment in any detail on the languages of the sources he discusses.

47 Nickelsburg, "Enoch, Levi, and Peter: Recipients of Revelation in Upper Galilee," 440.

48 Nickelsburg, “Enoch, Levi, and Peter: Recipients of Revelation in Upper Galilee," 441. 
provenance of the written Enoch traditions, even of chapters 12-16. Their hesitation rests not least on the stronger suggestion that the various toponyms in the Levi traditions might be better identified with sites in the Shechem region. The plausibility of their suggestions is endorsed by the constant association of Levi's concern for the rape of Dinah by Shechemites with Shechem itself, but the mention of Hermon has then to be explained away as an error. For our purposes this might only be of interest as a vague hint of Luke's concern with the region of Samaria.

Nickelsburg moves beyond consideration of 1 En. $6-16$ and the Testament of Levi to wonder whether several Petrine traditions can similarly be associated with the same geographical region. His starting point is the revelation described in Matt 16 as Peter is established as the rock. And he then proposes that passages in both 1 Pet 3:19-20 and 2 Pet 2:4-5 know of Enochic traditions, the latter of which seems to revise a borrowing from Jude which cites Enoch explicitly. Nickelsburg also notes how there is evidence for the continuing association of Peter and Enoch in the Akhmîm manuscript which preserves the only extant copies in Greek of the Gospel of Peter, the Apocalypse of Peter, and the text of 1 En. 1-32. The Gospel of Peter 41-42 reflects 1 Pet 3:19-20.

What of Luke's geography? Is he aware of the possible Galilean context for the development of some of these traditions? It is possible, though he does not seem to make anything of it. ${ }^{49}$ If he knew the Petrine tradition as exemplified in Matt 16, he comments on it through omission; more likely, his concern is to locate the concerns of his Aramaic source materials with Jerusalem, redirecting their eschatological interests in Jerusalem to the present age. In this way, Luke's use of Jerusalem as a geographical focus is all the stronger not simply for what it asserts positively, not least as that is reinforced with the way he has resurrection appearances only in Jerusalem and its environs, but also as it seems to be written against the Galilean contexts and their implications for some aspects of the very sources he seems to rely on.

This essay has taken a brief look at three traditions that involve special Lukan material. All three have been shown to have resonances of textual material that

49 In my study of some of the parallels between Luke and John, I discussed the common appearance in both of the miraculous draft of fishes, in both variously used with regard to the call of Peter. I failed to note there the possible implications of the Galilean basis of Matt 16 for the same purposes. 
seems to have been originally cast in Aramaic, as if Luke had access to a set of such traditions and reflected upon them. How did his reflection work? Nudged by the Jesus traditions available to him in Mark and Q, and in juxtaposition to popular knowledge about the Roman Emperor, Luke developed an explicit and enhanced interest in Jesus as Son of God, Son of the Most High. As in Mark, that sonship was recognized by demons, but Luke gives such recognition an increased authenticity by setting it in a longer tradition of the understanding of sickness and possession. And such understanding is part of Aramaic sources that pay attention to the source of healing lore in Enoch and what he passed on to his descendants. The very passages that enhance Luke's view of what Jesus was heir to are also those which help him adopt and slightly adapt his received genealogy of Jesus. Some of the Aramaic sources from the Qumran caves can now be seen as providing a set of interrelated motifs and topics to which Luke could make direct or indirect appeal.

Beyond what might be reconstructed as sayings of Jesus, further study might reveal yet more of Aramaic origin in Luke's special material. For example, the way the majestic anagnoreisis of Luke's Emmaus resurrection account (Luke 24:31) is most nearly matched in contemporary Jewish literature in the recognition of the accompanying Raphael in the book of Tobit (Tob 12:15-16), again originally in Aramaic.

\section{Bibliography}

Barr, James. “Aramaic-Greek Notes on the Book of Enoch I." Jss 23 (1978): 184-98.

Barr, James. Review of The Books of Enoch, by Józef T. Milik.JTs 29 (1978): 517-30.

Barr, James. "Aramaic-Greek Notes on the Book of Enoch II." Jss 24 (1979): 179-92.

Bauckham, Richard J. Jude, 2 Peter. WBC 20. Waco, TX: Word Publishing, 1983.

Bauckham, Richard J. Jude and the Relatives of Jesus in the Early Church. Edinburgh:

T\&T Clark, 1990.

Brooke, George J. "Luke, John and the Dead Sea Scrolls." Pages 69-91 in John, Qumran, and the Dead Sea Scrolls: Sixty Years of Discovery and Debate. Edited by Mary L. Coloe and Tom Thatcher. SBLEJL 32. Atlanta, GA: SBL, 2011.

Collins, John J. “The Background of the 'Son of God' Text." BBR 7 (1997):51-62.

Collins, John J. “The Aramaic Texts from Qumran: Conclusions and Perspectives." Pages 547-62 in Aramaica Qumranica: Proceedings of the Conference on the Aramaic Texts from Qumran in Aix-en-Provence 3oJune-2 July 20o8. Edited by Katell Berthelot and Daniel Stökl Ben Ezra. STDJ 94. Leiden: Brill, 2010.

Cook, Edward M. “4Q246.” ввR 5 (1995): 43-66.

Cook, Edward M. "Qumran Aramaic, Corpus Linguistics, and Aramaic Retroversion." DSD 21 (2014): 373-83. 
Dimant, Devorah. "Themes and Genres in the Aramaic Texts from Qumran." Pages 15-43 in Aramaica Qumranica: Proceedings of the Conference on the Aramaic Texts from Qumran in Aix-en-Provence 3o June-2 July 2008. Edited by Katell Berthelot and Daniel Stökl Ben Ezra. ST DJ 94. Leiden: Brill, 2010. Repr. as pages 195-218 in Devorah Dimant, History, Ideology and Bible Interpretation in the Dead Sea Scrolls: Collected Studies. Fat 9o. Tübingen: Mohr Siebeck, 2014.

Duke, Robert R. The Social Location of the Visions of Amram (4Q543-547). StBibLit 135. New York: Peter Lang, 2010.

Eshel, Hanan, and Esther Eshel. "Separating Levi from Enoch: Response to 'Enoch, Levi, and Peter: Recipients of Revelation in Upper Galilee'. Pages 458-68 in George W. E. Nickelsburg in Perspective: An Ongoing Dialogue of Learning. Edited by Jacob Neusner and Alan J. Avery-Peck. JSJSup 8o. Leiden: Brill, 2003.

Feldman, Ariel. "Patriarchs and Aramaic Traditions." Pages 469-80 in T\&T Clark Companion to the Dead Sea Scrolls. Edited by George J. Brooke and Charlotte Hempel. London: T\&T Clark, 2019.

Fitzmyer, Joseph A. "The Languages of Palestine." свQ 32 (1970): 501-31. Repr. as pages 29-56 in idem, A Wandering Aramean: Collected Aramaic Essays. SBLms 25. Missoula: Scholars Press, 1979.

Fitzmyer, Joseph A. "The Contribution of Qumran Aramaic to the Study of the New Testament." NTS 20 (1973-74): 382-407. Repr. as pages 85-113 in idem, A Wandering Aramean, Collected Aramaic Essays. s blms 25. Missoula: Scholars Press, 1979.

Fitzmyer, Joseph A. "The Aramaic 'Son of God' Text from Qumran Cave 4." Pages 16378 in Methods of Investigation of the Dead Sea Scrolls and the Khirbet Qumran Site: Present Realities and Future Prospects. Edited by Michael O. Wise, Norman Golb, John J. Collins and Dennis G. Pardee. Annals of the New York Academy of Sciences 722. New York: The New York Academy of Sciences, 1994.

Flusser, David. "The Hubris of the Antichrist in a Fragment from Qumran." Imm 10 (1980): 31-37.

Franklin, Eric. "Luke." Pages 922-59 in The Oxford Bible Commentary. Edited by John Barton and John Muddiman. Oxford: Oxford University Press, 2001.

Hengel, Martin. Son of God. London: scm Press, 1976.

Joosten, Jan. “The Verb g'r 'to Exorcise' in Qumran Aramaic and Beyond." DSD 21 (2014): 347-55.

Joseph, Simon J. The Nonviolent Messiah: Jesus, $Q$, and the Enochic Tradition. Minneapolis, MN: Fortress Press, 2014.

Jung, Chang-Wook. The Original Language of the Lukan Infancy Narrative. JSNTSup 267. London: T\&T Clark International, 2004.

Knibb, Michael A. The Ethiopic Book of Enoch: A New Edition in the Light of the Aramaic Dead Sea Fragments. 2 vols. Oxford: Clarendon Press, 1978.

Kochenash, Michael. “'Adam, son of God' (Luke 3:38): Another Jesus-Augustus Parallel in Luke's Gospel." NTS 64 (2018): 307-25. 
Kratz, Reinhard G. "Son of God and Son of Man: 4Q246 in the Light of the Book of Daniel." Pages 9-27 in Son of God:Divine Sonship in Jewish and Christian Antiquity. Edited by Garrick Allen et al. University Park, PA: Eisenbrauns, 2019.

Machiela, Daniel A. The Dead Sea Genesis Apocryphon: A New Text and Translation with Introduction and Special Treatment of Columns 13-17. STDJ 79. Leiden: Brill, 2009.

Machiela, Daniel A. "Luke 13:10-13: 'Woman, You Have Been Set Free From Your Ailment'-Illness, Demon Possession, and Laying on of Hands in Light of Second Temple Period Jewish Literature." Pages 122-37 in The Gospels in First-Century Judaea: Proceedings of the Inaugural Conference of Nyack College's Graduate Program in Ancient Judaism and Christian Origins, August 29th, 2013. Edited by R. Steven Notley and Jeffrey P. García. Jewish and Christian Perspectives 29. Leiden: Brill, 2015.

Nickelsburg, George W. E. "Enoch, Levi, and Peter: Recipients of Revelation in Upper Galilee," JBL 100 (1981): 575-6oo. Repr. as pages 427-57 in vol. 2 of George W. E. Nickelsburg in Perspective: An Ongoing Dialogue of Learning. Edited by Jacob Neusner and Alan J. Avery-Peck. JSJSup 8o. Leiden: Brill, 2003.

Paffenroth, Kim. The Story of Jesus according to L. JSNTSup 147. Sheffield: Sheffield Academic Press, 1997.

Perrin, Andrew B. The Dynamics of Dream-Vision Revelation in the Aramaic Dead Sea Scrolls. JAJSup 19. Göttingen: Vandenhoeck \& Ruprecht, 2015.

Puech, Émile. "246. 4QApocryphe de Daniel ar." Pages 165-84 in Qumran Cave 4.XVII: Parabiblical Texts, Part 3. Edited by James C. VanderKam. DJD 22. Oxford: Clarendon Press, 1996.

Segal, Michael. "Who is the 'Son of God' in 4Q246? An Overlooked Example of Early Biblical Interpretation." DSD 21 (2014): 289-312.

Steudel, Annette. "The Eternal Reign of God-Collective Expectations in Qumran Texts (4Q246 and 1QM)." RevQ 17 (1996): 507-25.

Stuckenbruck, Loren. "Qumran Aramaic' Today: Reflections on the Contributions in the Issue of Dead Sea Discoveries." DSD 21 (2014): 277-88.

Suter, David W. "Why Galilee? Galilean Regionalism in the Interpretation of 1 Enoch 6-16." Hen 25 (2003): 167-212.

Tigchelaar, Eibert J. C. "Aramaic Texts from Qumran and the Authoritativeness of Hebrew Scriptures: Preliminary Observations." Pages $155^{-71}$ in Authoritative Scriptures in Ancient Judaism. Edited by Mladen Popović. JSJSup 141. Leiden: Brill, 2010.

Tuckett, Christopher M. Review of The Story of Jesus according to L, by Kim Paffenroth. NovT 41 (1999): 191-92.

Twelftree, Graham H.Jesus the Exorcist. WUNT II.54. Tübingen: Mohr Siebeck, 1993. Yarbro Collins, Adela, and John J. Collins. King and Messiah as Son of God. Grand Rapids, MI: Eerdmans, 2008. 